\title{
GIFTS AND CONFLICTS OF INTEREST: IN SHADES OF GRAY? ${ }^{1}$
}

\author{
Diana Pasmanik Volochinsky², Raúl Villarroel Soto ${ }^{3}$, María Inés Winkler²
}

\begin{abstract}
Gifts are a regular practice within the relationships established by business world stakeholders with the professionals that may be instrumental in promoting their sales. Consequently, gifts are a potential source of conflicts of interest. This article is the result of a bibliographic study of papers addressing gifts, published in scientific journals which was carried out with the aim of identifying what kinds of professions address the issue and in what ways, in order to reach conclusions that may enhance reflection and contribute to professional training. The research was carried out using the SciELO, PsychNet, IEEE, and Proquest databases and yielded 59 publications that span the period between 1998 and 2015 . Results show a remarkable concentration in health-related professions, mainly in their relationships with the pharmaceutical industry. Nevertheless, an emerging presence is being observed in other professional fields. Starting from a philosophical conceptualization of the gift as a present, the results suggest that it is not this conception of gift but rather the exchange rationality that is reflected in these practices, thus becoming an ethically gray, i.e., uncertain area, that cannot be disregarded when it comes to training in professional ethics.
\end{abstract}

Key words: gift, conflict of interest, professions, pharmaceutical industry

\section{Los regalos como conflicto de interés: ¿Una zona gris?}

Resumen: Los regalos son una práctica habitual en las relaciones que establecen los actores del mundo empresarial con aquellos profesionales que pueden potencialmente promover sus ventas. Por ello, constituyen fuente de eventuales conflictos de interés. Este artículo es el resultado de un estudio bibliográfico de artículos publicados en revistas científicas acerca de los obsequios con el propósito de identificar en qué tipos de profesiones el tema es tratado y de qué maneras, para arribar a conclusiones que enriquezcan la reflexión y contribuyan en la formación profesional. La pesquisa se efectuó a través de las bases SciELO, PsychNet, IEEE y Proquest, dando como resultado 59 publicaciones que abarcan el período comprendido entre 1998 y 2015 y que muestran una notoria concentración en las carreras de la salud, principalmente en sus relaciones con la industria farmacéutica. A pesar de ello, se aprecia una presencia emergente en carreras de otros campos profesionales. Partiendo de una conceptualización filosófica del regalo en cuanto don, los resultados inducen a concluir que no es esta concepción de regalo la que se expresa en estas prácticas sino la racionalidad del intercambio, constituyéndose en una zona éticamente gris, es decir, incierta, que resulta insoslayable en la formación en ética profesional.

Palabras clave: regalo, conflicto de interés, profesiones, industria farmacéutica

\section{Presentes e conflitos de interesses: uma área cinza?}

Resumo: A troca de presentes é uma prática regular dentro das relaçôes estabelecidas no mundo de negócios, o que pode ser um instrumento na promoção de vendas. Consequentemente, os presentes são uma fonte potencial de conflitos de interesses. Este artigo é o resultado de um estudo bibliográfico de trabalhos que abordam presentes, publicados em revistas científicas, que foi realizado com o objetivo de identificar quais os tipos de profissóes que abordam essa questáo e de que maneira, a fim de chegar a conclusóes que possam reforçar a reflexão e contribuir para a formaçáo profissional. A pesquisa foi realizada usando os bancos de dados da SciELO, PsychNet, IEEE e Proquest e foram encontradas 59 publicaçóes que abrangem o período entre 1998 e 2015. Os resultados mostram uma notável concentração nas profissóes relacionadas com a área da saúde, principalmente relacionadas com a indústria farmacêutica. No entanto, uma presença emergente está sendo observada em outros campos profissionais. A partir de uma conceituação filosófica do presente como um regalo, os resultados sugerem que não é essa concepção de presente, mas sim o intercâmbio de racionalidade que é refletida nestas práticas, tornando-se um ponto de vista ético cinza, ou seja, uma área incerta, que náo pode ser ignorado no âmbito do ensino da ética profissional.

Palavras-chave: presente, conflito de interesses, profissôes, indústria farmacêutica

\footnotetext{
${ }^{1}$ Trabajo financiado por PIA-CONICYT proyecto SOC 1110, modalidad Anillos de Investigación en Ciencias sociales y la Universidad de Santiago de Chile.

${ }^{2}$ Escuela de Psicología, Universidad de Santiago de Chile, Chile

Correspondence: diana.pasmanik@usach.cl

${ }^{3}$ Centro de Estudios de Ética Aplicada y Departamento de Filosofía, Universidad de Chile, Chile
} 


\section{Introduction}

Probity is an important issue addressed in the regulations of different public and private institutions across the world. Coming from the Latin probitas, the term refers to honesty(1). Any potential source of corruption or conflict of interest increasing the likelihood that personal gain may supersede compliance with the transcendent and collective purposes inherent to a professional activity hinders the achievement of probity.

Related to the above, a recurring topic, detected during the development of a research project aimed at strengthening ethics in professional training ${ }^{4}$, has been the issue of gifts, considered whether as institutional presents, as "courtesies" upon the closing of an agreement, or as presents provided for special dates, such as Christmas or others.

This finding led to the search for information to obtain deeper understanding of the social and work setting associated with this issue. In what follows, a philosophical standpoint will first be adopted in order to provide a preliminary conceptualization of the gift issue; then, the gift will be addressed within the framework of conflicts of interest to subsequently present the perspective or understanding of this phenomenon by professionals themselves by means of published papers. The above will enable an examination of the complexities of the institutionalized practice of presenting gifts, analyzing its distinctive characteristics and discussing the possibility that such practice may somehow compromise probity in the behavior of those involved.

This article explores the experience of presenting gifts, understood in this case as the circulation of presents in the professional world, recognizing that this practice poses the risk of introducing a bias in the beneficiaries' judgment, restricting their objectivity and, in extreme cases, even corrupting them. The research is focused on a review of papers published in scientific journals concerning gifts in the professional environment with the aim of identifying what kinds of professions address the issue and in what ways, in order to reach conclusions that may enhance reflection on an

${ }^{4}$ Refer project complete name and identification details. issue that has an indisputable ethical relevance and enabling its subsequent incorporation into professional training.

\section{Philosophical conceptualization of the problem}

In contemporary reflection, the gift issue has been extensively addressed. It is understood that this term refers to something that is inherently gratuitous, both in the sense that it is something that cannot be estimated in terms of a price and in the sense that it is something that may be obtained at no cost. "Gratuitous, as when we say something without an argument to sustain it and gratuitous as when we give or do something without asking anything in return or without it having any cost" (2). The Being "gives itself" said Heidegger; it gives itself in the form of its "occurrence" (Ereignis)(3), and this occurrence would be the most gratuitous thing.

Certainly, the philosophical conceptualization of the gift has been closely linked to reflection concerning temporality. The reason for this is that it is often stated that what is given in a truly authentic manner is not what is announced or expected. A gift always refers to something unforeseen, unexpected. A gift is characterized by suddenness, i.e., it irrupts into experience and it is presented to us in a manner that does not give us time to be prepared to receive what is being given to us, because what is being given comes about inopportunely, not related to any forecasts or anticipated calculations whatsoever. The gift is a gift precisely because it is not anticipated. Here lies the inestimable value of every true gift. A gift occurs when it surprises, when the person who receives it has neither intended to promote it nor is expecting it.

Moreover - we could add, if allowed-, it is like the Heideggerian Erignis irrupting in the midst of idle talk (Gerede) and calculative thinking (rechnendes Denken), believing it can control and tamper with everything at its discretion, when everything seems absolutely ready for its control and gain, including both nature and human life, history, and the future. Then, the unforeseen "occurrence" of the Being - according to Heidegger-, the "gift" implied in it, only demands expectation, opening, and resolution to go out and meet all the 
unforeseen and invaluable that is given through such occurrence, which is the Being.

The French philosopher Jacques Derrida is one of the contemporary thinkers who, in an asymptotic affiliation with Heideggerian philosophy, has thoroughly and extensively addressed the gift issue, from the earliest concerns critically linked to the anthropological studies about gifts in primitive societies in the work by Marcel Mauss (Of Grammatology, 1967) to later studies such as Given Time (1991).

But Derrida tries to give up the rationale of recognition for which the gift is the source of identical and identifiable subjects(4). If the concept of gift is not examined outside such recognition scheme - according to Derridait will be impossible to go beyond the rationale of identity, inextricably linked to domination and the sacrifice of otherness, because every gift, every present, is offered under the expectation of self-recognition. The gift, then, because it is an unforeseeable event, is -in a certain way- violent, because it implies that the person who receives it becomes the slave of the person who gives it since, due to its ineffability and unpredictability, the former cannot return the gift during the same act of giving.

It could be inferred, at least provisionally, that if the gift is recognized as such, if it is identified in terms of an occurrence and its unpredictability is avoided, then it is denaturalized because giving (the gift) cannot appear to be something managed, since this would mean that it has entered into the circle of interests, thereby immediately becoming part of a rationale of exchanges, donations, and the corresponding returns and mandatory retributions.

The above circumstance makes the gift issue particularly interesting when analyzed within the context of late-capitalist societies, where the prevailing moral rationale is that of selfish individualism, leading mainly to actions within contexts of mere economic exchanges. As a result, a reflective approach to the gift in institutional environments in market societies regulated by the economic exchange matrix leads us to deeply ethical critical considerations with respect to the validity of certain gifts or presents through which the situation described by Derrida, i.e., a merchandise that is also a poison, may come into effect.

As a partial synthesis, when transferred to institutional and professional environments, the practice of encouraging professional performance or the execution of agreements of any kind through the provision of incentives in the form of gifts, presents a complexity that must be thoroughly examined in order to reveal, as required, both its potential harmlessness or presumable benefits and its obscurities or deleterious effects in the social sphere. When the gift is not inherently gratuitous but its occurrence creates a debt, then it becomes an instrument of domination.

\section{The gift under the framework of conflicts of interest}

The gift being defined as an element that in latecapitalist societies may become a managed present finds a space, in as much as it is a source of ethical risk, in the conflict of interest. Arellano, Lepore and Guajardo(5), referring to public officers, make a difference between an actual, a potential, and an apparent conflict of interest. In an actual conflict, interests, whether personal or family interests, has affected a person's work performance; therefore, we are dealing with a form of corruption. A potential conflict of interest refers to situations in which there is likely for the event to occur, but actual occurrence will depend on circumstances that may change the officer's context. An apparent conflict of interest refers to those situations in which it is possible to suspect the presence of a conflict, even if there is no conflict, affecting the image of the officer and the general trust in the public system. From this perspective, they state, giving a false appearance of conflict of interest is a moral error because it undermines public trust with respect to the government's impartiality and autonomy.

In business, Zhuang and Tsang(6) refer to gifts as part of exchange systems, placing them among the practices of what they call "gray marketing" to refer to the use of methods that could be considered ethically problematic, although they 
are not punished, such as dinner invitations, gifts, and undue commissions "as a means of getting orders or establishing beneficial relationships" (p. 86), which practices, they state, would be habitual in different industries, among them the pharmaceutical and medical instrumentation industry.

In this way, based on the distinctions that identify a potential conflict of interest and from the standpoint of "gray marketing", the existence of a risk factor, an uncertain area, is recognized, whether due to the absence of consensus with respect to its moral condition or because the individual is subject to conditions and circumstances that may make him or her stumble.

\section{Method}

The search for information was carried out during February, March, and April 2016, focusing on digitally available bibliographic resources. First, the SciELO journal database was searched through the Google.cl search engine, using the terms "Gift Policy SciELO", "Gifts SciELO", and "SciELO accepting gifts and ethicsin education". A total of 15 publications were found, 12 of which correspond to the field of medicine, one to pharmaceutics, and two to education. APA PsycNET of the American Psychological Association, the IEEE, an online database produced and distributed by the Institute of Electrical and Electronics Engineers, and Proquest were also searched. Each search on SciELO was suspended after no new information was found on two consecutive pages using Google. cl. As search terms were attempted in the APA PsycNET and IEEE publication databases "Gifts and ethics", "Gifts and relationships", and "Gifts and relationships and education", showing a total of six publications.
The search in Proquest database was carried out based on a more specific term, due to the large amount of results obtained. Thus, the search term was "accepting gifts and ethics in education", in publications with complete texts and evaluated by experts. A total of 3,645 references were found and were organized based on their relevance. The 60 first titles were reviewed, with 33 being relevant. Out of these, 21 corresponded to medicine, three to nursing, one to the pharmaceutical field, one to education, three to criminology, and four to business.

The texts were subject to simple content analysis and the resulting information was coded and organized in emerging categories.

\section{Results}

The search yielded 59 publications in which gifts appear as an element for discussion within the framework of professional and academic relationships. The criteria applied to define the incorporation of a publication were that it referred to a profession recognized as such, as medicine, psychology, nursing, pharmacy, engineering, and education, or to a field of specialization, such as counseling in education which was included under education, or that at least one of the publications referred to the teaching of the discipline at a university or to the tertiary education of the professionals in the field, thereby enabling the incorporation of the publications referring to criminology and business.

The texts are organized in the table below based on their area of knowledge or work performance, the range of years of the publications found per subject area and subareas associated with gifts or gratuities (a concept present in publications in the field of criminology), and the calculation of the total share of the area in the publications found. 


\begin{tabular}{|c|c|c|c|}
\hline $\begin{array}{l}\text { Area of Knowledge or Work } \\
\text { Performance }\end{array}$ & Subject Areas & References* & $\begin{array}{l}\text { Number } \\
\text { (Percentage) } \\
\end{array}$ \\
\hline \multirow[t]{9}{*}{ Medicine (1998-2014) } & & & $37(62,7)$ \\
\hline & $\begin{array}{l}\text { Theoretical contributions to conflict of } \\
\text { interest's understanding }\end{array}$ & $(7-13)$ & 7 \\
\hline & $\begin{array}{l}\text { Relationships with the pharmaceutical } \\
\text { industry }\end{array}$ & $(14-32)$ & 19 \\
\hline & Training & $(33-35)$ & 3 \\
\hline & The philanthropy of grateful patients & (36) & 1 \\
\hline & Relevance of ethics & (37) & 1 \\
\hline & Conflicts associated with the librarian role & (38) & 1 \\
\hline & $\begin{array}{l}\text { Patient and laymen perceptions about } \\
\text { physicians receiving gifts or additional } \\
\text { payments }\end{array}$ & (39) & 1 \\
\hline & $\begin{array}{l}\text { Ethical problems and therapeutic } \\
\text { boundaries and training (psychiatry) }\end{array}$ & $(40-43)$ & 4 \\
\hline \multirow[t]{2}{*}{ Nursing (2008-2009) } & & & $3(5,1)$ \\
\hline & $\begin{array}{l}\text { Relationships with the pharmaceutical } \\
\text { industry }\end{array}$ & $(44-46)$ & 3 \\
\hline \multirow{2}{*}{$\begin{array}{l}\text { Pharmaceutics (2007 y } \\
\text { 2012) }\end{array}$} & & & $2(3,4)$ \\
\hline & $\begin{array}{l}\text { Relationships with the pharmaceutical } \\
\text { industry and training }\end{array}$ & $(47-48)$ & 2 \\
\hline \multirow[t]{3}{*}{ Psychology (2004-2008) } & & (5) & 8,5 \\
\hline & $\begin{array}{l}\text { Relationships with the pharmaceutical } \\
\text { industry }\end{array}$ & (49) & 1 \\
\hline & Ethical problems and therapeutic limits & $(50-53)$ & 4 \\
\hline \multirow[t]{2}{*}{ Engineering (2014) } & & (2) & $2(3,4)$ \\
\hline & Training & $(54,55)$ & 2 \\
\hline \multirow[t]{4}{*}{ Education (2008-2013) } & & & $3(5,1)$ \\
\hline & Counselors in education & (56) & 1 \\
\hline & Teachers and conflicts of interest & $(57)$ & 1 \\
\hline & $\begin{array}{l}\text { Professional ethics and training of } \\
\text { university professors }\end{array}$ & (58) & 1 \\
\hline \multirow[t]{3}{*}{ Criminology (2003-2005) } & & (3) & $3(5,1)$ \\
\hline & Gratuities & $(59,60)$ & 2 \\
\hline & Training & $(61)$ & 1 \\
\hline \multirow[t]{4}{*}{ Business (2003-2015) } & & & $4(6,7)$ \\
\hline & Individual and organizational variables & $(62,63)$ & 2 \\
\hline & Conflicts of interest in business practices & (7) & 1 \\
\hline & Training & $(64)$ & 1 \\
\hline Total & $1998-2015$ & & $59(100)$ \\
\hline
\end{tabular}

* The numbers in parenthesis correspond to the number of the bibliographic reference as they appear in the corresponding section. 
The analysis of the texts enabled the classification of 55 of the 59 publications into three groups based on their main content, with the boundaries in the relationship between the professionals and the clients or users being identified in eight publications, ethical training in nine, and conflicts of interest in 39 papers.

The problems associated with professional boundaries are present in four psychiatry publications and four psychology publications. A relevant aspect here is the wellbeing of the person who presents the gift, towards whom the professional has a responsibility and therefore must have the necessary cultural sensitivity for prudent decision-making. A similar suggestion concerning cultural sensitivity and gifts is proposed for police agents(60).

The papers referring to ethical training, including gifts, presents, and gratuities as part of the contents being dealt with, amount to a total of nine publications, covering six of the eight identified areas of knowledge or work performance.

The conflict of interest appears in 35 publications in health care, including medicine, nursing, pharmaceutics, and psychology. There are also two publications in the field of criminology under the denomination of gratuities $(59,60)$, one in education(58), and one in business(63). Conflicts of interest in relationships with the pharmaceutical industry are addressed as a main subject in 25 publications, including, in addition to medicine(14-32), nursing(44-46) and psychology(49), two professions that are incorporated because nurses and doctors in clinical psychology are certified to prescribe medication in the United States. The issue is also present in papers in the pharmaceutical field, associated with training $(47,48)$. The recognized ethical risks are related to the concern for the impact of gifts on the professional's judgment when it comes to decisionmaking, affecting the patient or client wellbeing. The influence of the pharmaceutical and medical supply industry operates through scholarships in support of graduate studies(25), donations for research, and financing of publications in scientific journals, which may potentially generate a bias in the selection of the articles to be published, favoring the involved industry(14).
The reactions of professionals and students in face of gifts provided by the pharmaceutical and medical instrumentation industry include a spectrum of positions, from the minimization of the impact of institutional gifts on the professional(28), the recognition of benefits from relationships with the pharmaceutical industry such as support for the organization and the attendance to scientific events(44), the valuation of the medical sales representative as an intermediary agent between the health professional and new medications (29), the danger to the professional's objectivity(9), to the professional's reliability in face of the society which he serves $(12,26)$. It is also stated that the influence of the pharmaceutical industry reaches patients associations, which are supported by them(11). The risk of disease commodification or mongering, basically consisting in promoting awareness with respect to illnesses and the "need" for medications to improve health conditions(22), is also discussed. The phenomenon is observed, for example, in potentially over-diagnosed cases, such as attention deficit disorders and depression. Another example is breastmilk replacement with substitutes(23).

In the field of business, there are discussions with respect to the so-called "gray ethics" and its implications for international business(6). In the educational area, warnings are given against the ethical risk of receiving presents from publishers and industries selling educational resources in exchange for using their books and other resources. At the same time, from university teachers' perspective, receiving gifts from students was ethically questionable, though not ethically unacceptable(58).

\section{Discussion}

The results highlight the potential and actual impact of gifts, presents, and gratuities on the professionals' work performance, affecting decision-making. Mauss and Lévi-Strauss already mentioned this fact in their studies concerning gifts, which, within the context of social relationships, operate as exchanges, i.e., they imply reciprocity(65). Therefore, gifts encourage predictable, interested, and potentially compromising relationships. 
In the field of medicine, which is by far the most extensively studied area, recent evidence indicates that physicians' medication prescription frequency would be affected by the fact of receiving money from the pharmaceutical industry(66), giving support to the above results. Moreover, publications dating from the 1990s indicate an increase in the prescription of pharmaceutical products from specific industries by physicians who had received support in the form of money for attendance to scientific events, whether as speakers or participants, as well as for research funding $(67,68)$. One explanation for the minimization of the impact of accepting gifts is the influence of the seductive capacity of the pharmaceutical industry and rationalization by professionals - refuted by the evidence- in relation to their capacity to differentiate information sources based on their quality and the importance assigned to the medical sales representative as an efficient means for keeping pace with new developments(29). Another explanatory factor is a self-serving bias(6-8), which becomes evident when people evaluate themselves as being better than others. In this case, professionals believe that gifts from the pharmaceutical industry will not distort their professional judgment, although this could happen to others. It is an unconscious bias and, therefore, it escapes the rational control of the individual.

Within this context and considering the incipient development of this issue in other professions, the example of the health professions in their efforts to address this problem is remarkable. In addition, there is evidence of increasing sensitization with respect to the issue, both within the medical profession -reflected in the guidelines provided by medical organizations and associations, like the Academia Chilena de Medicina (Chilean Academy of Medicine) (20) —and the pharmaceutical industry itself and its search for indirect alternatives to support the activities of associations, professionals, and students(30). This could be a way to address the need to face and modify its relationship patterns, concerning which the review carried out reaches the conclusion that there is an undeniable dependence on relationships that implicitly lead to reciprocity and deprive the professionals from the necessary autonomy and impartiality.

The concern for relationships that may introduce a bias in professional decisions, by means of gifts or other circumstances, generating conflicts of interest, justifies early incorporation of this issue as a relevant content in professional degree programs. As there are no clear indications concerning the possibility of a zero-tolerance kind of decision as a public policy or a legal regulation, it is necessary to denaturalize the practices of giving gifts and gratuities, by transforming them into objects of analysis and discussion within the framework of an ethical training promoting ethos in each profession and a sense of individual responsibility towards users or clients as well as towards the professionals themselves.

\section{Acknowledgments}

This paper was possible due to the Team Grants for Research in Social Sciences and Humanities 2011 (Project SOC 1110). The authors wish to thanks CONICYT and the University de Santiago de Chile for their support. 


\section{References}

1. Diccionario de la Lengua Española, online. Definición de probidad. 2016 [cited 2016 Mar 29] Available from: http:// dle.rae.es/?id=UEI8LOD

2. Beuchot, M. Justicia y caridad: El don. Without editorial reference [cites 2016 Mar 2] Available from: http://www.uca. edu.ar/uca/common/grupo75/files/beuchot.pdf

3. Heidegger, M. Caminos de bosque. Madrid: Alianza; 2003.

4. Derrida, J. Dar (el) tiempo. I. La moneda falsa. Barcelona: Paidós; 1995.

5. Arellano Gault D, Lepore W, Guajardo Mendoza D. ¿¿Hacia un Sistema Integral de Evaluación del Desempeño? Situación actual de la regulación federal mexicana para la construcción y uso de indicadores de desempeño. Política Interior 2009; 2(4): 109-149.

6. Zhuang G, Tsang AS, L. A Study on Ethically Problematic Selling Methods in China with a Broaden Concept of Graymarketing. J Bus Ethics 2008; 79(1-2): 85-101.

7. García MC, Ortega D, Biagini L. Interacciones industria \& radiologia: logros innegables, conflictos de intereses posibles. Los obsequios de la industria. Rev. chil. Radiol. 2006; 12(4): 179-185.

8. Jadresic E, Correa E. El conflicto de intereses en medicina: una preocupación de la Sociedad de Neurología, Psiquiatría y Neurocirugía (SONEPSYN). Rev. chil. neuro-psiquiatr. 2004 ; 42(1): 22-28.

9. Maj M. Financial and non-financial conflicts of interests in psychiatry. Acta Bioethica 2009; 15(2): 165-171.

10. Arribalzaga EB. ¿Conflictos de interés o intereses en conflicto? Rev Chil Cir 2008; 60(5): 473-480. http://dx.doi. org/10.4067/S0718-40262008000500019

11. La Rosa Rodríguez E. Los conflictos de intereses. Acta Bioethica 2011; 17(1): 47-54. http://dx.doi.org/10.4067/S1726569X2011000100006

12. Lama TA. El médico y los conflictos de intereses. Rev. méd. Chile 2003; 131(12): 1463-1468. http://dx.doi.org/10.4067/ S0034-98872003001200015

13. Tagle P, Godoy J, Heerlein A, et al. Conflicto de interés: una reflexión impostergable. Panel del comité editorial. Rev. chil. neuro-psiquiatr. 2004; 42(1): 09-21.

14. Heerlein A. Recomendaciones para un control de los conflictos de interés en medicina. Rev. chil. neuro-psiquiatr. 2005; 43(2): 83-87.

15. Salas SP, Osorio FM, Vial CP, et al. Conflicto de intereses en la práctica clínica: Análisis ético de algunas relaciones con la industria. Rev. méd. Chile 2006; 134(12): 1576-1582. http://dx.doi.org/10.4067/S0034-98872006001200014

16. Lemmens T, Singer PA. Bioethics for clinicians: 17. Conflict of interest in research, education and patient care. Canadian Medical Association Journal 1998; 159(8): 960-965.

17. Rotondo MT. Relaciones profesionales: conflictos de intereses. Rev. Méd. Urug. 2006; 22(2): 88-99.

18. Lama A. Los médicos y la hospitalidad de la industria. Rev. méd. Chile 2004; 132(2): 265-268. http://dx.doi. org/10.4067/S0034-98872004000200019

19. Lama A. Los congresos médicos de especialidades: algunas reflexiones. Rev. méd. Chile 2013; 141(5): 674-675. http:// dx.doi.org/10.4067/S0034-98872013000500018.

20. Armas R, Beca JP, Heerlein A, et al. Documento de la Academia Chilena de Medicina sobre las relaciones entre los médicos y la industria proveedora en salud. Rev. méd. Chile 2014; 142(10): 1338-1340. http://dx.doi.org/10.4067/ S0034-98872014001000016.

21. Gómez Córdoba AI, Latorre Santos C, Carreño JN. Dilemas éticos en las relaciones entre la industria farmacéutica y los profesionales de la salud. Pers. Bioét. 2007; 11(1): 23-38.

22. Morell Sixto ME, Martínez González C, Quintana Gómez JL. Disease mongering, el lucrativo negocio de la promoción de enfermedades. Rev Pediatr Aten Primaria 2009; 11(43): 491-512.

23. Vallone F. Pequeños grandes clientes: la publicidad de sucedáneos de la leche materna en dos revistas pediátricas de Argentina entre 1977 y 2006. Salud Colectiva 2009; 5(1): 87-105. http://dx.doi.org/10.1590/S1851-82652009000100006

24. Macilwain C. Scientists defy their ethics codes and take gifts from industry. Nature 1998; 392(6675): 427.

25. Square D. Does that free sleeve of golf balls demean the profession? Canadian Medical Association Journal 2003; 168(7): 884.

26. Kondro W. Industry handouts: enough is enough. Canadian Medical Association Journal 2008; 178(13): 1651-1652.

27. Opar A. Medical students protest perks from drug companies. Nat Med 2006; 12(10): 1104.

28. De Maria AN. Your Soul for a Pen? J Am Coll Cardiol 2007; 49(11): 1220-1222. 
29. Matthews R. Hooked: Ethics, the Medical Profession, and the Pharmaceutical Industry. The Journal of Nuclear Medicine 2008;49(12): 2068-2069.

30. Goold SD, Campbell EG. Industry Support of Continuing Medical Education: Evidence and Arguments. Hastings Cent Rep 2008; 38(6): 34-37.

31. Steinbrook R. Physician-Industry Relations — Will Fewer Gifts Make a Difference? N Engl J Med 2009; 360(6): $557-$ 559.

32. Ganzini L, Chen Z, Peters D, et al. Medical Student Views on Interactions With Pharmaceutical Representatives. Academic Psychiatry 2012; 36(3): 183-187.

33. Goodman RL. Medical education and the pharmaceutical industry. Perspect Biol Med 2007; 50(1): 32-39.

34. Randall ML, Rosenbaum JR, Rohrbaugh RM, Rosenheck RA. Attitudes and Behaviors of Psychiatry Residents Toward Pharmaceutical Representatives Before and After an Educational Intervention. Academic Psychiatry 2005; 29(1): 33-39.

35. Roberts LW, Warner TD, Green Hammond KA, Geppert CMA, Heinrich T. Becoming a Good Doctor: Perceived Need for Ethics Training Focused on Practical and Professional Development Topics. Academic Psychiatry 2005; 29(3): 301-309.

36. Wright SM, Wolfe L, Stewart R, et al. Ethical Concerns Related to Grateful Patient Philanthropy: The Physician's Perspective. Journal of General Internal Medicine 2013; 28(5): 645-651.

37. Gabel S. Ethics and Values in Clinical Practice: Whom Do They Help? Mayo Clin Proc 2011; 86(5): $421-424$.

38. Tooey MJ, Arnold GN. The impact of institutional ethics on academic health sciences library leadership: a survey of academic health sciences library directors. Journal of the Medical Library Association 2014; 102(4): 241-246.

39. Baji P, Pavlova M, Gulácsi L, Groot W. Exploring consumers' attitudes towards informal patient payments using the combined method of cluster and multinomial regression analysis - the case of Hungary. BMC Health Services Research 2013; 13: 62 .

40. Lapid M, Moutier C, Dunn L, et al. Professionalism and Ethics Education on Relationships and Boundaries: Psychiatric Residents' Training Preferences. Academic Psychiatry 2009; 33(6): 461-469.

41. Smolar AI. Reflections on gifts in the therapeutic setting: The gift from patient to therapist. Am J Psychother 2002; 56(1): 27-45.

42. Kaplan A. Gifts from Patients: Pragmatic Model Offers Guidance. Psychiatric Times 2007; 24(13): 1

43. Fennig S, Secker A, Treves I, Motti BY, et al. Ethical Dilemmas in Psychotherapy: Comparison Between Patients, Therapists and Laypersons. Isr J Psychiatry Relat Sci 2005; 42(4): 251-257.

44. FEEDBACK. Can Nurse 2008; 104(6): 4-6.

45. Hagen B, Pijl-Zieber E, Souveny K, Lacroix A. Let's do lunch? Can Nurse 2008; 104(4): 30-35.

46. Crock E. Ethics of pharmaceutical company relationships with the nursing profession: No free lunch.... and no more pens? Contemporary Nurse: a Journal for the Australian Nursing Profession 2009 10; 33(2): 202-209.

47. Rojas Ochoa F. La publicidad comercial de medicamentos también es corrupción. Rev Cubana Salud Pública 2012; 38(4): 500-501.

48. Piascik P, Bernard D, Madhavan, S, et al. Gifts and Corporate Influence in Doctor of Pharmacy Education. Am J Pharm Educ 2007; 71(4): 1-68.

49. Reist D, Van de Creek L. The Pharmaceutical Industry's use of Gifts and Educational Events to Influence Prescription Practices: Ethical Dilemmas and Implications for Psychologists. Professional Psychology: Research and Practice 2004; 35(4):329-335. http://dx.doi.org/10.1037/0735-7028.35.4.329

50. Zur O. Boundaries in Psychotherapy: Ethical and Clinical Explorations. Washington, DC: Psychological Association; 2007. http://dx.doi.org/10.1037/11563-011

51. Knox S, DuBoir R, Smith, J, et al. Clients' experiences giving gifts to therapists. Psychotherapy: Theory, Research, Practice, Training 2009; 46(3): 350-361. http://dx.doi.org/10.1037/a0017001

52. Knapp SJ. Van de Creek LD. Multiple relationships and professional boundaries. In: Practical ethics for psychologists: A positive approach. Washington, DC: American Psychological Association; 2006, 75-97. http://dx.doi.org/10.1037/11331006

53. Brown C, Trangsrud HB. Factors associated with acceptance and decline of client gift giving. Professional Psychology: Research and Practice 2008; 39(5): 505-511. doi:10.1037/0735-7028.39.5.505

54. Grossenbacher L, McGlamery TD. Lessons learned from a year in the trenches: Teaching engineering ethics for P.E. licensure requirements. Ethics in Science, Technology and Engineering 2014. IEEE International Symposium on: 1 - 6, doi: 10.1109/ETHICS.2014.6893439

55. Randy LG. [Ethically Speaking]. IEEE Antennas and Propagation Magazine 2014, 56(6): 254-255, doi: 10.1109/ MAP.2014.7011067 
56. Pack-Brown S, Thomas TL, Seymour JM. Infusing Professional Ethics Into Counselor Education Programs: A Multicultural/Social Justice Perspective. Journal of Counseling and Development 2008; 86(3): 296-302.

57. Pérez Castro J. Ética profesional y formación de profesores universitarios. Perfiles educativos 2013; 35(142): 33-42.

58. Hirsch Adler A. Dilemas, tensiones y contradicciones en la conducta ética de los profesores. Sinéctica 2011; (37): 1-16.

59. Brandon DP. One Dogma of Police Ethics: Gratuities and the "Democratic Ethos" of Policing. Criminal Justice Ethics 2005; 24(2): 25-46.

60. Coleman S. When Police Should Say “No!” to Gratuities. Criminal Justice Ethics 2004; 23(1): 33-44.

61. Lord VB., Bjerregaard BE. Ethics courses: Their impact on the values and ethical decisions of criminal justice students1. Journal of Criminal Justice Education 2003; 14(2): 191-211.

62. García-Sánchez I, Rodríguez-Domínguez L, Frías-Aceituno JJ. Board of Directors and Ethics Codes in different corporate governance systems. J Bus Ethics 2015; 131(3): 681-698.

63. Perryer C, Tsahuridu E. An exploration of influences on attitudes to giving and receiving gifts. Asia Pacific Management Review 2013; 18(3).

64. Giacalone RA, Jurkiewicz CL, Knouse SB. A capstone project in business ethics: Building an ethics training program. Journal of Management Education 2003; 27(5): 590-607.

65. Bourdieu P. Razones prácticas sobre la teoría de la acción. Barcelona: Editorial Anagrama;1997.

66. Ornstein Ch, Mike Tigas M, Grochowski Jones R. Now There’s Proof: Docs Who Get Company Cash Tend to Prescribe More Brand-Name Meds. ProPublica March 17, 2016. Available from: https://www.propublica.org/article/doctors-who-take-company-cash-tend-to-prescribe-more-brand-name-drugs?utm_campaign=bt_twitter\&utm source=twitter\&utm_medium $=$ social

67. Orlowski JP, Wateska L. The effects of pharmaceutical firm enticements on physicians prescribing patterns. There's no such thing as a free lunch. Chest 1992; 102: 270-273.

68. Chren MM, Landefeld CS. Physician's behaviour and their interaction with drug companies. A controlled study of physicians who requested additions to a hospital drug formulary. JAMA 1994; 271: 684-689.

Received: May 10, 2016

Accepted: June 9, 2016 